\title{
Title VII and Congressional Employees: The "Chilling Effect" and the Speech or Debate Clause
}

Protection from discrimination in employment on the basis of race, creed, sex, and place of national origin is a fundamental national policy of constitutional dimension. ${ }^{1}$ Congress, however, has consistently exempted itself from its own fair employment laws, ${ }^{2}$ gaining for itself a reputation as the nation's "last plantation." Extension to congressional employees of the protection from discrimination in employment provided by Title VII of the Givil Rights Act of $1964^{4}$ is currently under consideration. ${ }^{5}$ Such legislation may conflict with the speech or debate clause of the federal constitution, ${ }^{6}$ which, as a means of fostering an independent and untramelled legislative process, has traditionally protected individual Senators and Representatives from judicial and executive interference.

This Note formulates judicial guidelines for implementing extension of Title VII to Congress in a manner reconciling the competing values of

1. See, e.g., Davis v. Passman, 442 U.S. 228 (1979) (implying cause of action for sex discrimination in employment under Fifth Amendment); Washington v. Davis, 426 U.S. 229 (1976) (employment discrimination action under equal protection clause of Fourteenth Amendment).

2. Congress is exempt from Title VII of the Civil Rights Act of 1964, 42 U.S.C. $\$ \S 2000 \mathrm{e}$ to 2000e-17 (1976 \& Supp. III 1979), the Equal Pay Act of 1963, 29 U.S.C. $\$ 206$ (1976), and the Age Discrimination in Employment Act of 1967, 29 U.S.C. $\$ \$ 621-634$ (1976 \& Supp. III 1979).

3. The sobriquet has been frequently applied. to Congress. See, e.g., North, Congress: The Last Plantation, BARRISTER, Fall 1978, at 46, 50; Comment, The Last Plantation: Will Employment Reform Come to Capitol Hill? 28 CATH. U.L. REV. 271 (1979); Alexander, Discrimination in Hiring and Pay Starts at the Top ... On Capitol Hill, reprinted in Handling of Discrimination Complaints in the Senate: Hearing Before the Comm. on Governmental Affairs, 95th Cong., 1st \& 2d Sess., pt. 1, at 3-7 (1977-1978).

4. 42 U.S.C. $\$ \S 2000$ e to $2000 \mathrm{e}-17$ (1976 \& Supp. III 1979). Section 2000e-2(a) prohibits discrimination in employment by private employers and state governments on account of an individual's race, color, religion, sex, or national origin.

5. S. 1112, 96th Cong., 1st Sess. (1979), reprinted in To Eliminate Congressional and Federal Double Standards: Hearing Before the Subcomm. on Oversight of Government Management of the Comm. on Governmental Affairs on $S .1112,96$ th Cong., 1st Sess. $79-83$ (1979) [hereinafter cited as Double Standards]. The Civil Rights Act of 1964, 42 U.S.C. $\$ 2000 \mathrm{e}-16$ (a) (1976) prohibits discrimination in employment on the basis of race, color, sex, or national origin in those units of the legislative branch of the federal government having positions in the competitive services. Section 2(a) of S. 1112 extends coverage to those units of the legislative branch not in the competitive services. Section 2(b) provides that, with respect to employment in the legislative branch (except the Library of Congress), the Equal Employment Opportunity Commission (EEOC) shall exercise the enforcement authorities granted to the Civil Service Commission by 42 U.S.C. $\$ 2000 \mathrm{e}-16$ (1976). The enforcement functions of Title VII in federal employment, originally vested with the Civil Service Commission by 42 U.S.C. $\$ 2000$ e-16(b), (c) (1976), have been transferred to the EEOC. Reorg. Plan No. 1 of 1978, 3 G.F.R. 321 (1978 Compilation), reprinted in 5 U.S.C. app., at 354 (Supp. III 1979) and in 92 Stat. 3781 (1978).

6. "[F]or any Speech or Debate in either House, [the Senators and Representatives] shall not be questioned in any other Place." U.S. CONST. art. I, $\$ 6$, cl. 1. 
equal opportunity in employment and legislative independence. The Note describes the problem of discrimination on Capitol Hill, evaluates existing approaches to discrimination, and recommends external administrative and judicial remedies. After describing the current framework for speech or debate analysis, the Note shows how that framework fails adequately to accomplish the clause's goal of preventing inhibition of the legislative process, and why such inhibition would be a significant problem in Title VII extension in particular. The Note realigns speech or debate clause doctrine to promote the doctrine's protection of the overall legislative process, and then applies the realignment in the specific context of a Title VII remedy.

\section{The Need for a Statutory Remedy}

Serious, longstanding discrimination in employment exists on Capitol Hill. Because other remedies for the discrimination would be ineffective, Congress should extend the protections of Title VII to its own employees.

\section{A. The Dimensions of the Problem}

Women and minorities are seriously underrepresented in higher level congressional employment. ${ }^{7}$ In addition, instances of overt discrimination, such as the Congressional Placement Office's adherence to employer requests for "no blacks," "no Catholics," and "no minorities," have been reported. ${ }^{8}$ The potential for discrimination may arise from the highly discretionary character of congressional employment. The majority of employees in the federal legislative branch work in institutional units that support the work of congressional committees and individual legislators,?

7. In this usage, "underrepresentation" denotes a smaller representation of a protected group (such as women and blacks) in a particular job category than in the general population. For example, as of 1980 , only $20.5 \%$ of employees occupying the highest ranking position in a Member's office, administrative assistant, were women. Capitol Hill Women's Political Caucus, The Last Plantation? How Women Fare on Capitol Hill 33 (Sept. 1980) (printed monograph) (on file with Yale Law Journal). As of 1977, a disproportionately small number of blacks occupied the top position on House stafi. HOUSE COAMIISSION ON ADMINISTRATIVE REORGANIZATION AND LEGISLATIVE MANAGEMENT, H.R. DOC. NO. 232, 95th Cong. Ist Sess. 93 (1977) [hereinafter cited as OBEY COMMISSION]. In 1980, the mean salary in staff positions was $\$ 16,058$ for women and $\$ 22,569$ for men. The Obey Commission found that in the House women earned less than men with comparable education, and blacks less than whites. Id. at 89 . The Commission concluded that sex and race explain "some significant portion of the variation in salary levels." Id. at 97. Similarly, at comparable professional levels women in Senate positions earn less than men. Capitol Hill Women's Political Caucus, supra, at 26. A group of black professionals in the Senate has estimated that 76 Senators employ no blacks in professional capacities on personal or committee staffs. Handling of Discrimination Complaints in the Senate: Hearing Before the Comm. on Governmental Affairs, 95th Cong., 1st \& 2d Sess., pt. 1, at 2 (statement of Sen. Glenn) [hereinafter cited as Discrimination Complaints].

8. North, supra note 3, at 48. See also Graves, The Congressional Double Standard, COMMON CAUSE, Oct. 1980, at 15-17 (examples of sexual harassment of women professional employees).

9. Such units include, for example, the Architect of the Capitol, the Congressional Budget Office, 
and policies governing employment among the units vary in formality. ${ }^{10}$ Moreover, direct employment by individual legislators ${ }^{11}$ and congressional committees ${ }^{12}$ is practically standardless, with few procedures and guidelines for hiring and promotion. Employment on personal and committee staffs is, owing to the nature of the institution, highly politicized, ${ }^{13}$ and even staff for nonpolicymaking positions are sometimes hired in part for political compatibility and loyalty. ${ }^{14}$

\section{B. Inadequacy of Existing Remedies}

Both the courts and Congress have fashioned remedies for employment discrimination on Capitol Hill. None of their remedies, however, could address the problem of employment discrimination as effectively as Title VII enforcement.

and the Capitol Police Force. The legislative branch employs approximately 40,000 people. C. BROWNSON, CONGRESSIONAL STAFF DIRECTORY ii, iv (23d ed. 1981).

10. U. S. SENATE, 94Th CONG., 2D SESS., SENATE AdMINISTRATION: A COMPILATION OF PAPERS PREPARED FOR THE COMMISSION ON THE OPERATION OF THE SENATE 69-78 (Comm. Print 1976) (little uniformity of hiring practices exists among largest Senate administrative units, with Sergeant at Arms and Secretary of Senate retaining almost unfettered control over hiring practices. Capitol Police Force, however, does have some formal procedures, such as position descriptions and formal announcement of higher level vacancies).

11. The Obey Commission found that so long as Members comply with House rules regarding total staff size, total salaries, and nepotism, they have complete discretion in employment decisions. OBEY COMMISSION, supra note 7, at 82 . Because of the diversity in size of Senate offices, salaries of personal staff members tend to be personalized and inequitable as among different offices. STAFF OF THE COMMISSION ON THE OPERATION OF THE SENATE, 94TH CONG., 2D SESS., SENATORS: OFFICES, ETHICS, AND PRESSURES 13 (Comm. Print 1977) [hereinafter cited as OFFICES, ETHICS, AND PRESSURES]. Especially at the professional levels, recruitment is largely by word of mouth, with minorities and women at a consequent disadvantage. SENATE COMM. ON GOVERNMENTAL AFFAIRS, LEE MET. CALF FAIR EMPLOYMENT RELATIONS RESOLUTION, S. REP. NO. 729, 95th Cong., 2d Sess. 15 (1978) [hereinafter cited as FAIR EMPLOYMENT RELATIONS RESOLUTION]. The homogeneity of staff members engaged in legislative policymaking arguably affects the nature of the legislation produced. Thus, employment practices on Capitol Hill may adversely affect not only the individuals involved, but the representativeness of the legislative process.

12. The Obey Commission found that, like hiring in House offices, recruitment by committees tends to be informal and ad hoc in nature. OBEY COMMISsION, supra note 7, at 102. Most House committees do not have formalized job descriptions, id. at 105, or performance evaluations, id. at 107. See SENATE COMMISSION ON THE OPERATION OF THE SENATE, TOWARD A MODERN SENATE, S. DOC. No. 278, 94th Cong., 2d Sess. 14-15 (1976) (recommending more structure in Senate personnel practices, including more detailed record-keeping, explicit statements of skills sought, and establishment of internal personnel evaluation systems).

13. See OBEY COMMISSION, supra note 7, at 112 (relationship between Member and personal staff not unlike that between President and White House staff in that "the Member's personal office staff is an extension of his or her political self'). The internal Senate rule prohibiting discrimination in employment was adopted with the understanding that it would not interfere with a Senator's prerogative to make employment decisions based upon political affiliation and compatibility. SPECIAL SENATE COMM. ON OFFICIAL CONDUCT, SENATE CODE OF OFFICIAL CONDUCT, S. REP. NO. 49, 95th Cong., 1st Sess. 53 (1977). The Obey Commission found that political loyalty is required also in House committee posts, although generally to a lesser degree than on Members' personal staffs. OBEY COMMISSION, supra note 7, at 113 .

14. See OBEY COMMISSION, supra note 7 , at 112 . 


\section{Constitutional Litigation: Davis v. Passman}

The Decisions. In the protracted litigation in Davis v. Passman, ${ }^{15}$ the federal courts began to fashion a constitutional remedy for congressional employment discrimination. Davis, a secretary discharged by former Congressman Otto Passman, argued that she could bring a Bivens-type suit ${ }^{16}$ in federal court directly under the Fifth Amendment for alleged sex discrimination. ${ }^{17}$ Agreeing that Davis could bring such a suit, a panel of the Court of Appeals for the Fifth Circuit held that, since Passman's dismissal of Davis was not a "legislative act," Davis' suit was not barred by the speech or debate clause. ${ }^{18}$ Although acknowledging that fear of burdensome litigation might deter a Congressman from firing a high-level aide and thus inhibit Members' deliberative role, ${ }^{19}$ the panel concluded that provision of a limited, "good faith" immunity would make the impact of such a fear on the legislative process remote. ${ }^{20}$ The Fifth Gircuit, en banc, reversed the panel on the issue of whether Davis could bring a Bivens-

15. 544 F.2d 865 (5th Cir. 1977), affd in part, vacated in part, 571 F.2d 793 (5th Cir. 1978) (en banc), rev'd on other grounds, 442 U.S. 228 (1979).

16. In Bivens v. Six Unknown Named Agents of Fed. Bureau of Narcotics, 403 U.S. 388 (1971), the Supreme Court held that petitioner could bring suit directly under the Fourth Amendment for money damages against agents of the Federal Bureau of Narcotics who had made, under color of federal Jaw, a warrantless entry of his apartment. See Rodriguez v. Ritchey, 539 F.2d 394, 400 (5th Cir. 1976) affd in part, rev'd in part, 556 F.2d 118 (5th Cir. 1977) (en banc), cert. denied, 434 U.S. 1047 (1978) (FBI agents could be held liable directly under Fourth Amendment for allegedly wrongful arrest); $c f$. Loe v. Armistead, 582 F.2d 1291, 1294 (4th Cir. 1978), cert. denied sub. nom. Moffitt v. Loe, 446 U.S. 928 (1980) (federal marshals could be held liable directly under Fifth Amendment for allegedly wrongful denial of medical treatment to federal pretrial detainee).

17. Although the equal protection clause of the Fourteenth Amendment applies only to the states, the Supreme Court has found an equal protection component applicable to the federal government in the Fifth Amendment's due process clause. See Bolling v. Sharpe, 347 U.S. 497, 499 (1954) (racial segregation in public schools in District of Columbia constitutes denial of due process guaranteed by Fifth Amendment).

18. Davis v. Passman, 544 F.2d 865, 880 (5th Cir. 1977), aff'd in part, vacated in part, 571 F.2d 793 (5th Cir. 1978) (en banc), rev'd on other grounds, 442 U.S. 228 (1979). But see Eslinger v. Thomas, 476 F.2d 225, 228 (4th Cir. 1973) (state legislators immune from suit under common-law speech-or-debate-type immunity for refusing to hire fermale law student as page when prohibition against hiring women as pages is embodied in state senate resolution). In reaching the conclusion that Davis's suit was not barred by the speech or debate clause, the Fifth Circuit panel noted that, on the basis of the record, it could not tell whether Davis's position gave her access to the legislative process. It was therefore unclear whether the suit would subject privileged material to scrutiny. $544 \mathrm{~F} .2 \mathrm{~d}$ at 880 n.25. Furthermore, the Court pointed out that evidence of discrimination in the case was patent. In his dismissal letter, Passman had written Davis that "on account of the unusually heavy workload in my Washington Office, and the diversity of the job, I concluded that it was essential that the understudy to my Administrative Assistant be a man." Id. at $867 \mathrm{n.1}$.

The Court in Davis did, however, afford Passman a qualified good-faith immunity analogous to that enjoyed by other government officials for charges of constitutional rights violations. See, e.g., Wood v. Strickland, 420 U.S. 308 (1975); Scheuer v. Rhodes, 416 U.S. 232 (1974). Nevertheless, the Court suggested that Passman could not use his limited immunity to obtain a motion for summary judgment because the constitutional prohibition of sex discrimination is clear and Passman therefore could not have made a good-faith mistake in failing to rely upon the prohibition. 544 F.2d at 880 .

19. Id. at 880 n.25.

20. Id. 
type suit under the Fifth Amendment ${ }^{21}$ and therefore did not consider whether Passman's action would be shielded by the speech or debate clause.

Reversing the Fifth Circuit en banc, the Supreme Court held that Davis could bring a Bivens-type suit. ${ }^{22}$ Since the Fifth Circuit en banc decision did not consider the speech or debate clause issue, the Court declined to reach it. ${ }^{23}$ The Court did say, however, that one of the clause's historic purposes, the prevention of harassment of legislators by groundless lawsuits, might be implicated by the case. ${ }^{24}$ It also held that judicial review of congressional employment decisions is constitutionally limited only by the reach of the speech or debate clause. ${ }^{25}$

Adequacy of the constitutional remedy. Although the shape of a Bivenstype remedy for congressional employees remains unclear, it seems likely that a statutory remedy under Title VII would better protect victims of congressional employment discrimination than would a direct action under the Constitution. First, liability under Title VII is easier to prove since no showing of discriminatory purpose is required. ${ }^{26}$ Second, unlike Title VII,

21. Davis v. Passman, 571 F.2d 793, 800 (5th Cir. 1978), rev'd, 442 U.S. 228 (1979).

22. Davis v. Passman, 442 U.S. 228, 248 (1979).

23. Id. at $235 \mathrm{n} .11,249$. The Court also did not reach the issue of whether Passman could assert a qualified good-faith immunity.

24. Id. at 235 n.11.

25. Id. The Court appears to have reached this conclusion by noting that " [i]n the American governmental structure the clause serves the . . . function of reinforcing the separation of powers so deliberately established by the Founders.' " Id. (quoting United States v. Johnson, 383 U.S. 169, 178 (1966)). Although the Court's language is broad, its conclusion might not operate in all contexts to preclude a legislator sued for employment discrimination from raising separation-of-powers arguments other than those grounded in the speech or debate clause. The Court might find generalized separation-of-powers issues raised by remedies enforced through the Equal Employment Opportunity Commission. Cf. Nixon v. Administrator of Gen. Servs., 433 U.S. 425, 443 (1977) (in determining whether act of legislature violates separation of powers between Executive and Congress, potential for disruption of executive branch functions must be balanced against policy objectives of legislation). In addition, litigation by higher ranking aides conceivably might create separation-of-powers concerns insofar as it would entail one branch's interference with the discretionary appointment of employees in another branch. Marbury v. Madison, 5 U.S. (1 Cranch) 137, 166 (1803) (acts of political agents of the President are only politically examinable); $c f$. Mayor of Philadelphia v. Educational Equality League, 415 U.S. 605, 615 (1974) (judicial oversight of mayoral appointments, when mayor had been charged with racial discrimination in appointments, would interfere with mayor's ability "to respond to the mandate of his constituency").

These generalized separation-of-powers concerns reflect institutional arrangements among the three branches. The speech or debate clause, however, comprehends not only the principle of separation of powers, but also a broader concern that the individual legislator's independence not be threatened by suit. See Davis v. Passman, 442 U.S. 228, 235 n.11 (1979) ("The purpose of the Clause is 'to protect the integrity of the legislative process by insuring the independence of individual legislators.' ") (quoting United States v. Brewster, 408 U.S. 501,507 (1972)). Thus, for example, it is highly doubtful that the speech or debate immunity of the individual legislator could be waived by an act of Congress. See Coffin v. Coffin, 4 Mass. 1, 27 (1808). This Note accepts, dubitante, the Court's holding in Davis that the speech or debate clause presents the only constitutional problem posed by judicial review of legislative employment decisions. The analysis therefore centers on the interference with the functioning of the individual legislator that discrimination suits may create.

26. Compare International Bhd. of Teamsters v. United States, 431 U.S. 324, 358 n.44 (1977) 
constitutional litigation requires no mandatory period of confidential conciliation and administrative investigation-a feature of Title VII that could help avert burdensome and costly litigation. ${ }^{27}$ Third, Title VII authorizes a wide range of equitable remedies such as backpay, reinstatement, and promotion; ${ }^{28}$ in contrast, the decision in Davis v. Passman expressly contemplates only damages remedies, ${ }^{29}$ and federal courts may be reluctant to grant equitable relief in federal government personnel matters in the absence of express statutory authorization for such relief. ${ }^{30}$ Fourth, Title VII, unlike a direct constitutional remedy, provides for the award of attorney's fees to plaintiffs. ${ }^{31}$ Finally, Title VII is generally more expeditious than constitutional litigation. ${ }^{32}$

\section{Internal Controls}

Although Title VII does not apply to most congressional employees, ${ }^{33}$ both the House of Representatives and the Senate have promulgated inter-

(individual Title VII suit does not require direct proof of discrimination but mere showing that employment action at issue did not result from lack of qualifications or absence of vacancy in job sought) (construing McDonnell Douglas Corp. v. Green, 411 US. 792 (1973)) with Washington v. Davis, 426 U.S. 229, $239-40$ (1976) (employment discrimination action under equal protection clause of Fourteenth Amendment, unlike Title VII action, requires some showing of racially discriminatory purpose). As compared with the standards of proof in a Title VII action, the standards in an action under the Fifth or Fourteenth Amendment are unsettled. See Double Standards, supra note 5, at 35-36 (statement of S. Shtasel, Special Assistant to the Associate Attorney General).

27. Sce 42 U.S.C. $§ 2000$ e-5(b) (1976) (private actions); 29 C.F.R. $\$ \S 1613.213$, 217 (1980) (suits against federal government employers). Informal conciliation is also advantageous to defendants in that it averts the public embarrassment that Members fear from discrimination suits. See FaIR EMPLOYMENT RELATIONS RESOLUTION, supra note 11, at 33 (concerns about possible political abuse of enforcement mechanism of internal Senate rule against employment discrimination); 124 CONG. REC. S18,246 (daily ed. Oct. 11, 1978) (remarks of Sen. Hollings) (concern about leaks of information from internal enforcement mechanism).

28. 42 U.S.C. $\S 2000 \mathrm{e}-5(\mathrm{~g})(1976)$. This authority is incorporated by reference for suits regarding federal employment. 42 U.S.C. $\S 2000$ e-16(d) (1976); see, e.g., Carreathers v. Alexander, 587 F.2d 1046, 1050-51 (10th Cir. 1978) (approving back pay as remedy in suit regarding federal employment); Smith v. Fletcher, 559 F.2d 1014, 1018 (5th Cir. 1977) (promotion); Clark v. Alexander, 489 F. Supp. 1236, 1248 (D.D.C. 1980) (reinstatement).

29. Davis v. Passman, 442 U.S. 228, 245 (1979). Since Passman was no longer a Member of Congress, equitable remedies such as reinstatement were not available.

30. See Sampson v. Murray, 415 U.S. 61, 83-84 (1974) (denying injunctive relief restraining government employee's dismissal before final administrative action in part because of reluctance to interfere with government's dispatch of its internal affairs).

31. 42 U.S.C. $\S 2000 \mathrm{e}-5(\mathrm{k})$ (1976) (made applicable to suits regarding federal employment by 42 U.S.C. $§ 2000$ e-16(d) (1976)).

32. See Double Standards, supra note 5, at 37 (statement of S. Shtasel, Special Assistant to the Associate Attorney General).

33. 42 U.S.C. § $2000 \mathrm{e}-16$ (a) (1976). It does, however, apply to employees of the federal government in the competitive service and in the Library of Congress, id., and also to state government employees except any person elected to public office "or any person chosen by such officer to be on such officer's personal staff," id. $\S 2000$ e(f). The competitive service includes most civil service positions in the executive branch and positions in other branches specifically included by statutes. 5 U.S.C. $\S 2102$ (1976 \& Supp. III 1979). 
nal rules prohibiting employment discrimination. ${ }^{34}$ None of these rules, however, provides adequate enforcement mechanisms. Although committees in both the House and the Senate have recommended the establishment of fair employment practices panels with mandatory enforcement mechanisms, ${ }^{35}$ neither recommendation has so far been adopted.

Current experience with the internal enforcement mechanisms suggests that these internal rules have little practical force on Capitol Hill. For example, although the House rule was promulgated early in $1975,{ }^{36}$ as of 1980 no Member had been charged with a violation of the rule. ${ }^{37}$ An impartial judicial and administrative procedure such as Title VII, free of legislative influence, would presumably be more effective than any internal mechanism ${ }^{38}$ the institutional independence of such remedies from Congress, though, is itself the source of speech or debate clause problems that Congress and the courts must solve.

34. House Rule XLIII, cl. 9, of the House Code of Official Conduct, reprinted in JEFFERSON'S MANUAl: RUles OF THE HOUSE OF RePRESENTATIVES, H.R. DOC. NO. 403, 96th Cong., 1st Sess. $\S 939$ (1978) (prohibiting employment discrimination by House Members, officers, or employees); SENATE COMM. ON RULES AND ADMINistration, 96TH CONG., 1ST SESS., STANDING RULES FOR Conducting Business in the United States Senate, Rule L (Comm. Print. 1979) (prohibiting employment discrimination by Senate Members, officers, or employees).

35. The Obey Commission recommended the creation of a Fair Employment Practices Panel that would hear confidential complaints and that might, if an accommodation with an allegedly discriminating Member could not be reached, refer the matter to the Committee on Standards of Official Conduct for possible disciplinary action. OBEY COMMISSION, supra note 7, at 118. A resolution was introduced to implement the House antidiscrimination rule, H.R. Res. 292, 96th Cong., 1st Sess., 125 CONG. REC. H3906 (daily ed. May 30, 1979), but to date no further action has been taken. Under current procedure a complaint that the House rule has been violated may be investigated by the Committee on Standards of Official Conduct, unless it is acting on its own initiative, only after the complainant has submitted it to at least three House Members who have refused in writing to transmit it to the Committee. The Committee can only recommend by majority vote referral to the full House for action. See Congressional Research Service, Library of Congress, Equal Employment Opportunity and the United States Congress 11 (Aug. 11, 1978) (on file with Yale Law Journal). Some Congressmen have established a Fair Employment Practices Committee, whose grievance panel, composed of three Members and three employees, may investigate discrimination complaints regarding Members who have signed a nondiscrimination pledge. The Committee, however, can only recommend action, and in any case, as of 1978, only 107 Members had signed the pledge. Id. at 12-13.

On the Senate side the enforcement of the anti-discrimination rule is vested in the Select Committee on Ethics. S. Res. 110, 95th Cong., 1st Sess., 123 CONG. REC. 10,061 (1977). The Select Committee may receive complaints, conduct an investigation, and recommend remedial action to the full Senate. SPECIAL SENATE COMM. ON OFFICIAL CONDUCT, supra note 13, at 86-88. The Committee on Governmental Affairs found, however, that "[e]xisting opportunities for administrative recourse within the Senate are clearly inadequate." FAIR EMPLOYMENT RELATIONS RESOLUTION, supra note 11, at 8. The Committee recommended the creation of a Fair Employment Practices Board composed of six members from the private sector. Discussion of the proposal on the Senate floor was tabled. 124 CoNG. REC. S18,248 (daily ed. Oct. 11, 1978).

36. H.R. Res. 5, 94th Cong., 1st Sess., 121 CONG. REC. 20 (1975).

37. See Graves, supra note 8 , at 19.

38. See, e.g., FAIR EMPLOYMENT RELATIONS RESOLUTION, supra note 11, at 18-19 (Fair Employment Relations Board composed of members outside Congress would insure both impartiality and public confidence). 


\section{The Speech or Debate Clause, Title VII, and the Chilling Effects of Litigation}

Job discrimination on Capitol Hill challenges Congress to extend Title VII to congressional employees without endangering the purposes underlying the speech or debate clause. Currently recognized speech or debate clause doctrine, however, fails adequately to fulfill the central rationale of the clause, the protection of the individual legislator's independence. The extension of Title VII to Congress without accommodation of the underlying purposes of the speech or debate clause would produce significant "chilling" effects" ${ }^{39}$ on legislative activity that the clause must protect.

\section{A. Speech or Debate Clause Doctrine}

Speech or debate clause doctrine has attempted to protect the independence of the the legislator while legislating. The current framework for speech or debate analysis, however, does not satisfactorily meet that goal.

\section{The Current Framework for Speech or Debate Clause Analysis}

Immunity for parliamentary activities became accepted as a fundamental part of the late seventeenth-century English constitution ${ }^{40}$ and had a place in the Bill of Rights of 1689.4 The English provision was adopted with little debate almost verbatim by the American constitutional convention in the speech or debate clause of Article $\mathrm{I}^{42}$ Legislative immunity has traditionally been applied to protect legislators from private suits, ${ }^{43}$ even

39. Chilling means the inhibition of socially useful activities on account of the actor's fear of possible adverse legal consequences. For example, in the First Amendment area of freedom of expression it usually refers to self-censorship, that is, needless self-repression of expression. See Herbert v. Lando, 441 U.S. 153, 159 (1979) (common law of libel tended to induce self-censorship of socially useful expression and therefore chilled First Amendment freedom of the press).

40. See C. WitTKe, THE History of ENGLish PARLIAMENTARY PRIVILEGE 15-16, 21 (1921); $c$. Reinstein \& Silverglate, Legislative Privilege and the Separation of Powers, 86 HARV. L. REV. 1113, 1122-35 (1973) (privilege evolved as practical instrument for security against executive).

41. "[T]he freedom of speech and debate or proceedings in Parliament ought not be impeached or questioned in any court or place out of Parliament." 1 W. \& M. Sess. 2, c.2 (1689). The acceptance of legislative privilege was a step in the development of Parliament as the supreme legislative body of the country. See Reinstein \& Silverglate, supra note 40, at 1135.

42. The usual explanation for the lack of debate at both the Constitutional Convention and the Ratification Debates is the general acceptance of the validity of the privilege. See, e.g., Reinstein \& Silverglate, supra note 40, at 1136. Madison at first argued that the legislative privilege should be specifically defined. After his proposal was rejected, he came to accept the wisdom of a broad, functional approach to the privilege. Id. at $1139-40$.

43. See Eastland v. United States Servicemen's Fund, 421 U.S. 491, 503 (1975) (clause applies equally to private civil suits and to criminal suits); Doc v. McMillan, 412 U.S. 306, 311-12 (1973) (same). Indeed, the Supreme Court, by affording a federal common-law speech-or-debate-type protection to state legislators sued in federal court for civil but not for criminal actions, has suggested that civil immunity may be more beneficial to society than criminal immunity. Compare Supreme Court of Va. v. Consumers Union of the United States, 446 U.S. 719, 734 (1980) (immunity from civil suit) and Tenney v. Brandhove, 341 U.S. 367, 377 (1951) (same) with United States v. Gillock, 445 U.S. 
in the face of claimed violations of plaintiffs' First Amendment rights.4

The Supreme Court has identified three functions for the immunity provided for in the speech or debate clause. First, it preserves Congress' institutional independence in the constitutional framework of separate and coequal branches. ${ }^{45}$ Second, it insulates legislators from the threat of liability based upon their legislative activity and thus prevents inhibition of the legislative process. ${ }^{46}$ Third, the privilege relieves a legislator from the burden and distraction incident to litigating a lawsuit involving legislative activities. $^{47}$

In implementing the speech or debate clause protection, the Court has always construed the clause to protect more than speech or debate in a legislative chamber. In its first case interpreting the clause, the Court held that it provided an immunity from liability for all activity generally done in relation to the business before Congress; ${ }^{48}$ the clause today protects all communicative and deliberative activity integral to the legislative process. ${ }^{49}$ The central feature of speech or debate clause analysis has therefore become classification of activities as "legislative" or "nonlegislative." Activities having the former quality, according to the Court, cannot provide a basis for claims against the legislator. ${ }^{50}$ The clause also provides a corre-

$360,372-73$ (1980) (no immunity from federal criminal prosecution).

44. See Tenney v. Brandhove, 341 U.S. 367, 377-78 (1951) (state legislators enjoy absolute speech-or-debate-type immunity in 42 U.S.C. $\$ 1983$ actions arising out of their investigation, even if their purpose was to interfere with plaintiff's First Amendment rights); Stamler v. Willis, $287 \mathrm{~F}$. Supp. 734, 739 (N.D. Ill. 1968), appeal dismissed, 393 U.S. 217 (1968) (interests embodied in speech or debate clause outweigh First Amendment rights).

45. United States v. Gillock, 445 U.S. 360, 369-70 (1980); United States v. Helstoski, 442 U.S. 477, 491 (1979).

46. See Gravel v. United States, 408 U.S. 606, 618 (1972) ("[The] fundamental purpose lof the clause is] freeing the legislator from executive and judicial oversight that realistically threatens to control his conduct as a legislator.") This purpose is closely connected with the purpose of maintaining separation of powers, see note 45 supra, since freedom from "possible prosecution by an unfriendly executive and conviction by a hostile judiciary," United States v. Johnson, 383 U.S. 169, 179 (1966), provides independence for both the legislative branch and the individual. However, even in circumstances where separation of powers concerns are not present, a speech-or-debate-type privilege serves to prevent disruption of the legislative process. See United States v. Gillock, 445 U.S. 360, 37172 (1980) (federal common-law speech-or-debate-type immunity for state legislators in civil suits justified by need to avoid disruption of legislative process) (citing Tenney v. Brandhove, 341 U.S. 367 (1951)).

47. Eastland v. United States Servicemen's Fund, 421 U.S. 491, 503 (1975); Dombrowski v. Eastland, 387 U.S. 82, 85 (1967).

48. Kilbourn v. Thompson, 103 U.S. 168, 204 (1881) (immunity applies to "things generally done in a session of the House by one of its members in relation to the business before it").

49. Gravel v. United States, 408 U.S. 606, 625 (1972) ("The heart of the Clause is speech or debate in either House. Insofar as the Clause is construed to reach other matters, they must be an integral part of the deliberative and communicative processes by which Members participate in committee and House proceedings with respect to the consideration and passage or rejection of proposed legislation or with respect to other matters which the Constitution places within the jurisdiction of either House.")

50. Hutchinson v. Proxmire, 443 U.S. 111, 127-33 (1979) (not everything done in relation to office of Member constitutes legislative activity for purposes of speech or debate clause); Gravel v. United States, 408 U.S. 606, 624-25 (1972) (although all legislative activities are performed by Mem- 
sponding evidentiary privilege, inasmuch as its prohibition of "questioning in any other place" has been read to forbid all reference to legislative acts in proceedings outside Congress. ${ }^{51}$

\section{Shortcomings of Present Judicial Analysis}

Current doctrine presents three related problems of legislative inhibition. First, a legislator may believe that he is undertaking an activity not protected by the speech or debate immunity as a matter of law, even though the act would be deemed by the courts to be legislative, simply because of vagueness in the doctrine. The legislator may then decline to pursue the activity. Second, even if the legislator is certain of the doctrinal protection afforded his actions, he may fear that a judge or jury will instead believe his opponent's version of the facts and will therefore find his actions unprotected. Such a legislator might adjust his own protected conduct in order to provide a basis for defense against civil liability. Finally, a legislator may adjust his protected conduct out of fear of burdensome litigation.

Substantive Doctrinal Uncertainty. Although the speech or debate clause clearly protects Members of Congress from liability arising from voting, ${ }^{52}$ floor debate, ${ }^{53}$ and committee deliberations, ${ }^{54}$ the full scope of the immunity is unclear. ${ }^{55}$ That lack of clarity arises from the breadth of the

bers of Congress in their official capacity, not everything done in this capacity qualifies as legislative act). Under current doctrine a Member of Congress enjoys an absolute immunity for any liability when the alleged wrongful act is legislative. See, e.g., Doe v. McMillan, 412 U.S. 306, 312 (1973) (liability may not be predicated on legislative activities); Tenney v. Brandhove, 341 U.S. 367,376 (1951) (state legislators enjoy absolute immunity from 42 U.S.C. $\$ 1983$ actions for "acts done within the sphere of legislative activity").

51. United States v. Helstoski, 442 U.S. 477, $488-89$ (1979) (legislative act may not be mentioned for purposes of proving existence of corrupt promise to vote favorably on certain private bills); United States v. Brewster, 408 U.S. 501, 528 (1972) (evidence of acts protected by speech or debate clause is inadmissible).

52. Doe v. McMillan, 412 U.S. 306, 311 (1973); Gravel v. United States, 408 U.S. 606, 617 (1972).

53. United States v. Johnson, 383 U.S. 169, 184-85 (1966).

54. Gravel v. United States, 408 U.S. 606, 628-29 (1972).

55. Compare Hutchinson v. Proxmire, 443 U.S. 111, 130 (1979) (press release about allegedly wasteful use of government grant funds not protected activity) with Ray v. Proxmire, 581 F.2d 998, 1000 (D.C. Cir.), cert. denied, 439 U.S. 933 (1978) (letter by Congressman in response to official inquiry, denying wife's use of Senate rooms for extra-legislative activity, is itself legislative activity). See generally Doe v. McMillan, 412 U.S. 306, 315 (1973) (legislative personnel as well as Representatives could be liable for taking part in public distribution of actionable material "beyond the reasonable bounds of the legislative task").

In the case of investigations by congressional committees, immunity depends on the factual circumstances of the investigation. Although the speech or debate clause normally protects a Member of Congress conducting an investigation, Eastland v. United States Servicemen's Fund, 421 U.S. 491, 504 (1975), the immunity is conditioned on the investigation being (1) within the jurisdiction of the congressional committee and (2) not in violation of either criminal law or the Fourth Amendment, McSurely v. McCellan, 553 F.2d 1277, 1287-88 (1976), cert. dismissed as improvidently granted sub nom. McAdams v. McSurely, 438 U.S. 189 (1978). While satisfaction of the first condition may not 
modern legislator's role. Representatives and Senators undertake a wide range of ex camera work related to the passage of bills ${ }^{56}$ and a correspondingly diverse range of constituent representation having little direct relationship to legislation. ${ }^{57}$

Ex camera work on bills and constituent services are not easily classified for the purposes of speech or debate analysis. The line through the large middle region between clearly "legislative" and clearly "nonlegislative" activities has wavered..$^{58}$ The lower courts charged with the implementation of the Supreme Gourt's distinction have repeatedly expressed the difficulty of applying the distinction. ${ }^{59}$ The confusions in the doctrine have rendered the legal status of various activities unpredictable to legislators. ${ }^{60}$

Under current doctrine, a legislator may therefore be uncertain about whether contemplated activity is legislative and thus within the protective scope of the clause. Faced by the possibility that the action will be held a proper basis for suit, liability, and questioning, a cautious legislator may refrain from such action, even if the action is in fact legislative in character. ${ }^{61}$ Such an inhibition, resulting from uncertainty about the substantive protections of the speech or debate clause, subverts the clause's basic purposes. $^{62}$

be difficult to ascertain, the second suffers from all the vagaries of determining what is a search and seizure in violation of the Fourth Amendment.

The potential for arbitrariness in the distinction between legislative and nonlegislative acts has been noted by at least one Justice. See Doe v. McMillan, 412 U.S. 306, 339 (1973) (Rehnquist, J., concurring in part and dissenting in part) ("completely ad hoc, factual determination" as to whether legislators enjoy immunity for public distributions renders privilege practically worthless).

56. See Suarez, Congressional Immunity: A Criticism of Existing Distinctions and A Proposal for A New Definitional Approach, 20 VILL. L. REV. 97, 129 (1974) ("[T]he very nature of representation precludes a simple division of the legislative process into internal and external activities.")

57. D. MAYHEW, CONGRESS: THE ELECTORAL CONNECTION 54-55 (1974) (each congressional office processes thousands of individual requests from constituents and other supplicants that do not require legislation); Cella, The Doctrine of Legislative Privilege of Speech or Debate: The New Interpretation as a Threat to Legislative Coequality, 8 SUFFOLK L. REV. 1019, 1074 (1974) (servicing of requests is legitimate and integral part of every Congressman's duties).

58. See note 55 supra.

59. See Hutchinson v. Proxmire, 431 F. Supp. 1311, 1321 (W.D. Wisc. 1977), affd, 579 F.2d 1027 (7th Cir. 1978), rev'd, 443 U.S. 111 (1979) ("[C]onsiderable confusion exists as to what constitutes legitimate legislative activity . . . ."); Schiaffo v. Helstoski, 492 F.2d 413, 417 (3d Cir. 1974) (limits of speech or debate clause "not clearly defined by judicial precedent"); Hoellen v. Annunzio, 468 F.2d 522 (7th Cir. 1973), cert. denied, 412 U.S. 953 (1972) (difficult to disentangle legislative from purely political qualities of acts). Commentators have also noted the confusion. See, e.g., Cella, supra note 57 , at 1069 ; Suarez, supra note 56 , at 137-38.

60. See JOINT COMIM. ON CONGRESSIONAL OPERATIONS, THE CONSTITUTIONAL IMMUNITY OF MEMiBerS OF CONGRESS, TESTIMONY AND ANALYSIS, S. REP. No. 896, 93d Cong., 2d Sess. 30 (1974) (reflecting confusion as to precise scope of legislative immunity).

61. The most sensitive area involves the information-gathering function of Congress, which is deemed essential for a legislative body. Watkins v. United States, 354 U.S. 178, 187-88 (1957).

62. See Doe v. McMillan, 412 U.S. 306, 343 (1973) (Rehnquist, J., concurring in part and dissenting in part) (law established categories of privilege for public officials because to submit them, " the innocent as well as the guilty, to the burden of a trial and to the inevitable danger of its 
The risk of nonpersuasion. The problem of doctrinal vagueness is not the only source of inhibition discouraging a legislator from engaging in legitimate activities. Current speech or debate clause doctrine also fails to take account of the difficulties a legislator faces in convincing a judge or jury of a favorable factual characterization of the activity under question. Often, for example, civil or criminal statutes make the actor's subjective intent an element of the cause of action or offense. ${ }^{63}$ Doubting his ability to prove absence of intent in court, a legislator may alter the normal conduct of his constitutionally protected activities so as to rebut any possible inference of intent, thus inhibiting the freedom of the legislative process. ${ }^{64}$

Burdensome litigation. The Supreme Court has frequently recognized that the speech or debate clause should be applied to minimize expensive and time-consuming litigation that would distract the legislator from the performance of his legislative duties. ${ }^{65}$ As the Court has recognized in other contexts, however, the mere fear of burdensome litigation can make an actor change his conduct of protected activities. ${ }^{66}$ Within the legislative context, the Court has failed to articulate the inhibitory effect of threatened or prospective litigation on proper legislative conduct.

outcome, would dampen the ardor of all but the most resolute, or the most irresponsible, in the unflinching discharge of their duties' ") (quoting Gregoire v. Biddle, 177 F.2d 579, 581 (2d Cir. 1949)). It is also evident that the courts have found the inhibition problem important enough to require absolute, rather than qualified, speech or debate immunity. United States v. Johnson, 383 U.S. 169, 181 (1966) (purpose of clause is "to prevent intimidation by the executive and accountability before a possibly hostile judiciary"); see United States v. Brewster, 408 U.S. 501, 516 (1972) (conscious choice of Framers to grant absolute immunity within scope of privilege).

63. See, e.g., MODEL PENAL CODE $\S \S 210.2-4$ (Official Draft 1962) (distinguishing among murder, manslaughter, and negligent homicide on basis of whether person who caused death acted purposely, knowingly, recklessly, or negligently).

64. The dissenting Justices in United States v. Brewster, 408 U.S. 501 (1972), emphasized the problem. Id. at 559 (White, J., dissenting) (even bribery statute limited to prohibiting payments that are put to personal use and are made in exchange for promise to perform a legislative act would inhibit congressional freedom of action because of factual problems of tracing campaign and personal funds). Justice White added: "The threat of prosecution for supposed missteps that are difficult to define and fall close to the line of what ordinarily is considered permissible, even necessary, conduct scarcely ensures that legislative independence that is the root of the Speech or Debate Clause." Id. at 558-59. Justice Brennan noted in his own dissenting opinion that "[t]he line between legitimate influence and outright bribe may be more a matter of emphasis than objective fact, and in the end may turn on the trier's view of what was proper in the context of the everyday realities and necessities of political office." Id. at 543 (Brennan, J. dissenting). See also Tenney v. Brandhove, 341 U.S. 367, 377 (1951) ("The privilege would be of little value if [legislators] could be subjected . . . to the hazard of a judgment against them based upon a jury's speculation as to motives.")

The risk of nonpersuasion is not limited to the problem of intent; it is common to all offenses or causes of action having an element that is sensitive to the prejudices and subjective judgment of the fact-finder. See note 124 infra (difficult in libel cases to establish truth of alleged defamatory statement before biased jury).

65. See p. 1466 \& note 47 supra.

66. In the First Amendment libel cases, it has been recognized that the prospect of the expense and distraction of litigation may be as chilling as the fear of actual liability. See Herbert v. Lando, 441 U.S. 153, 205 (1979) (Marshall, J., dissenting); Rosenbloom v. Metromedia, Inc., 403 U.S. 29, 52-53 (1971) (plurality opinion). 


\section{B. Chilling Effects of Title VII Enforcement}

Establishment of a Title VII remedy for discriminatory congressional employment practices would provide legislative employees with effective means for vindicating equal employment opportunity claims. On the other hand, like other antidiscrimination strategies, such a remedy would create a risk of chilling legislative activity that speech or debate clause doctrine has sought to protect, albeit unsuccessfully. ${ }^{67}$

\section{Sources of Chilling}

A Title VII suit threatens Congressmen with a burdensome defense of employment claims, hostile attempts to obtain confidential and possibly embarrassing information, ${ }^{68}$ and, ultimately, civil liability. A legislator who fears that his communication with aides may be revealed in the course of litigation, thus exposing him to political embarrassment and even providing a basis for a civil claim, may temper his candor in communicating with his aides on matters of policy or ideology. ${ }^{69}$ Threatened by

67. The controversy surrounding the applicability of speech or debate immunity to Title VII suits has centered on the question whether legislative employment is a legislative activity. On the one hand, it is asserted that discriminatory employment practices "are no more essential to legislating than receiving a bribe is to voting." Comment, supra note 3 , at 289 . On the other hand, it is argued that because aides are granted immunity for acts for which the Member would be immune, employment actions regarding such aides are legislative acts themselves. Brief of the United States as Amicus Curiae at 4, Davis v. Passman, 571 F.2d 793 (5th Cir. 1978) (en banc), rev'd on other grounds, 442 U.S. 228 (1979) (citing Gravel v. United States, 408 U.S. 606, 616-17 (1972)). Both arguments are unsatisfying. Legislative employment is as central to the deliberative core of legislating as taking a campaign contribution. By the same token, it is difficult to understand why the mere fact of extension of immunity to legislators' aides makes the employment relationship itself immune from questioning. More fundamentally, because classification of activities as either legislative or nonlegislative says little about the chilling effect of litigation on legislative activity, an inquiry about whether legislative employment is a legislative act sheds little light on the question of how a discrimination suit would affect the undeniably legislative functions of communication and deliberation about policy.

68. Emphasizing the literal language of the clause, the Court has made clear that the clause not only protects a legislator from liability for legislative acts, but also from questioning about these activities in a proceeding outside Congress. Gravel v. United States, 408 U.S. 606, 615 (1972). The Court also has suggested that communication between legislator and aide regarding legislative acts cannot be questioned by a grand jury. Id. at 628-29. There is also strong support for a general privilege of confidentiality. In Gravel, Senator Gravel moved to quash a grand jury subpoena directed to a staff member concerning how the Senator had obtained the Pentagon Papers. Justice Stewart, dissenting, recognized that without confidentiality a legislator would find it difficult to procure valuable information related by informants. Id. at 630 . He concluded that the speech or debate clause precluded any questioning of Senator Gravel about sources of information. Id. at 630-31. The other three dissenting Justices agreed with this observation. See id. at $662-63$ (Brennan, J., dissenting). Cf. Kaye, Congressional Papers, Judicial Subpoenas, and the Constitution, 24 U.C.L.A. L. REV. 523, 576-79 (1977) (Congress, like executive branch, needs some confidentiality to protect proper discharge of its functions). But see In re Grand Jury Investigation, 587 F.2d 589, 596-97 (3d Cir. 1978) (speech or debate clause forbids evidentiary use of certain information, but not its disclosure).

69. Direct empirical evidence of a chilling effect is difficult, if not impossible, to gather. See Community-Service Broadcasting of Mid-America, Inc. v. FCC, 593 F.2d 1102, 1118 (D.C. Cir. 1978) (en banc) ("Chilling effect is, by its very nature, difficult to establish in concrete and quantitative terms; the absence of any direct actions against individuals assertedly subject to a chill can be viewed as much as proof of the success of the chill as of evidence of the absence of any need for concern.") 
the prospect of litigation, he may refrain from firing or refusing to hire an aide for legitimate political or ideological reasons; a legislator's policy deliberations would thereby be inhibited. ${ }^{70}$ Although deliberations in Congress with respect to legislative policy are protected by the speech or debate clause, ${ }^{71}$ current doctrine does not adequately address inhibition of such deliberations by the threat of burdensome suit, disclosure, and liability. In the context of discrimination law, the chilling effects on legislative activity are particularly important, since Title VII is to a large extent enforced by the EEOC, a quasi-judicial, quasi-executive agency. ${ }^{72}$

\section{The Title VII Litigation Pattern}

Within the individual-plaintiff Title VII litigation pattern, three principal areas pose serious threats to speech or debate clause values. These are the investigation of private complaints and related judicial discovery, the proof of liability, and remedies. In each of these areas, Title VII enforcement could chill activity within the protective scope of the speech or debate clause. Current speech or debate clause doctrine, however, cannot reduce these chilling effects.

Investigation and discovery. The broad range of investigation and discovery that Title VII suits permit can heavily burden any defendant. ${ }^{73} \mathrm{~A}$ complainant must first file his charge with the EEOC, ${ }^{74}$ or, in the case of an employee of, or job applicant to, a federal agency, a delegate of the EEOC, ${ }^{75}$ which undertakes a confidential ${ }^{76}$ investigation. The scope of this

70. Legislative aides are hired to a large extent for their political compatibility with and loyalty to a particular legislator, see Discrimination Complaints, supra note 7, pt. 1, at 2 (statement of Sen. Glenn), and a large number of aides are intimately involved in the formulation of legislation.

In cases of professionals suing under Title VII, the courts have upheld the right of employers to employ on the basis of subjective factors unrelated to discrimination, see Peters v. Middlebury College, 409 F. Supp. 857, 868-69 (D. Vt. 1976) (college's subjective judgment of teaching ability permissible factor in decision not to extend plaintiff professor's contract); political compatibility, at least in the case of a policymaking employee on a Member's staff, would be one such subjective factor, $c f$. Elrod v. Burns, 427 U.S. 347, 367 (1976) (plurality opinion) (in the case of policymaking employees, political loyalty may be required to prevent obstruction of "implementation of policies of the new adminstration"). Under current doctrine, the Court may thus regard political compatibility as a legitimate factor in certain legislative employment decisions.

71. See p. 1466 supra (Gravel standard).

72. See 42 U.S.C. $\S 2000$ e-5 (1976) (EEOC evaluates charges, attempts reconciliation, and, if necessary, brings civil actions). The speech or debate clause should serve not only to free individual legislators from the threat of private suit, but also as Congress' main defense against executive and judicial interference within the constitutional sytem of separation of powers. See p. 1466 supra (one function of clause is to protect legislature from executive and judicial encroachment).

73. See S. Mazaroff, Surviving the Avalanche: Defendant's Discovery in Title VII Litigation, LITIGATION, Fall 1974, at 14.

74. 42 U.S.C. $\S 2000 \mathrm{e}-5(\mathrm{~b})$, (f) (1976). Timely filing of a discrimination charge with the EEOC is a prerequisite to bringing a private civil action under Title VII. If the EEOC takes no action within 180 days of the filing of the complaint, then the complainant may request a Notice of Right to Sue Letter, which allows him to bring a private action. 29 C.F.R. $\$ 1601.28$ (1980).

75. The Equal Employment Opportunity Act of 1972, § 11, 42 U.S.C. $\S 2000 \mathrm{e}-16$ (1976), ex- 
investigation may extend to all aspects of the employer's personnel decisionmaking, with the private party's charge serving as little more than a starting point for the administrative inquiry.$^{77}$ If a judicial complaint follows the investigation, the complaint may also encompass much more than the initial private charge. ${ }^{78}$ Although the initial investigation itself is confidential, the speech or debate clause protects legislators from any "questioning" regarding their legislative activities outside Congress, ${ }^{79}$ presumably including questioning by the EEOC. Nevertheless, the investigatory powers of the EEOC or its delegate, because of their potential for bur$\mathrm{den}^{80}$ and intrusion, could deter legislators from making legitimate employment decisions $\mathrm{s}^{81}$ and conferring candidly with aides about legislative matters. ${ }^{82}$

Although the limits of Title VII discovery may not be as broad as the initial investigation, ${ }^{83}$ some Title VII suits involving professionals have

tended to federal employees, with certain exceptions, the same right to effect administrative remedies and to bring private civil suits under Title VII as employees in the private sector had enjoyed under 42 U.S.C. $\$ 2000$ e-5 (1976). See H.R. REP. NO. 238, 92d Cong., 1st Sess. 22-23 (1971), reprinted in [1972] U.S. CODE CONG. \& AD. NEWS 2137, 2159-60. The Act incorporated by reference the procedures of 42 U.S.C. $\$ 2000 \mathrm{e}-5$ (1976) for litigating a private suit. 42 U.S.C. $\$ 2000 \mathrm{e}-16$ (d) (1976). The administrative component of $\S 2000 \mathrm{e}-16$, however, is somewhat different from that in $\S 2000 \mathrm{e}-5$; it requires the filing of complaints with the Director of Equal Employment Opportunity of the named agency, who processes the complaint under EEOC supervision and review. See 29 C.F.R. $\S 1613.204, .218(1980)$.

The proposed legislation to eliminate the Title VII exemption for Congress, S. 1112, 96th Cong., 1st Sess. 1 (1979), reprinted in Double Standards, supra note 5, at 79, places congressional employees under the protection of 42 U.S.C. $\$ 2000 \mathrm{e}-16(1976)$, thus granting congressional employees the administrative remedies presently enjoyed by federal agency employees.

76. 42 U.S.C. $\$ 2000 \mathrm{e}-5(\mathrm{~b})(1976)$ (requirement of confidentiality before filing private civil suit). Under 42 U.S.C. $\$ 2000 \mathrm{e}-16$ (1976), the confidentiality of investigations of federal employment is left unclear. See 29 C.F.R. $\$ 1613.216$ (1980) ("The agency shall authorize the investigator to administer oaths and require that statements of witnesses shall be under oath or affirmation, without a pledge of confidence.")

77. See EEOC v. General Elec. Co., 532 F.2d 359, 364 (4th Cir. 1976) (filing of charge merely triggers investigatory and conciliatory procedures of EEOC and does not limit investigation of discrimination to allegations in charge); Sanchez v. Standard Brands, Inc., 431 F.2d 455, 466 (5th Cir. 1970) (scope of EEOC investigation much broader than scope of administrative complaint).

78. The scope of the judicial complaint is defined by the scope of the EEOC investigation, which may itself be much broader than the EEOC charge. See Sanchez v. Standard Brands, 431 F.2d 455, 466 (5th Cir. 1970); Sylvester v. United States Postal Serv., 393 F. Supp. 1334, 1340 (S.D. Tex. 1975), affd, 595 F.2d 1219 (5th Cir. 1979) (Sanchez test applied in suit by federal employee pursuant to 42 U.S.C. $\S 2000 \mathrm{e}-16)(1976)$ ).

79. See United States v. Helstoski, 442 U.S. 477, $489-90$ (1979) (forbidding questioning by grand jury).

80. Since Title VII evidentiary burdens are low - that is, a case can be proved without direct evidence of discrimination, see note 26 supra-a great deal of evidence is arguably relevant at the investigation stage, and potential complainants are encouraged to file a charge if they have only a colorable claim. The threat of burdensome litigation is thereby increased.

81. See p. 1471 supra.

82. See p. 1470 supra; $c f$. Rosenbloom v. Metromedia, Inc., 403 U.S. 29, $52-53$ (1971) (plurality opinion) ("The very possibility of having to engage in litigation, an expensive and protracted process, is threat enough to cause discussion and debate to "steer far wider of the unlawful zone. . . ." )

83. It is unclear, for example, whether the EEOC investigative file is admissible evidence. Heard v. Mueller Co., 464 F.2d 190, 194 (6th Cir. 1972) (admissibility of EEOC's final investigative report 
permitted discovery of personnel files and evaluations of other employees in the workplace. ${ }^{84}$ Furthermore, once a civil suit is begun all information previously gathered by the EEOG investigation may be publicly disclosed ${ }^{85}$ Thus, the early stages of Title VII litigation involving legislators would exacerbate the chilling effects of disclosure and questioning during the administrative investigation.

Proof of liability. In McDonnell Douglas Corp. v. Green, ${ }^{86}$ the Supreme Court set forth the order for proof of a plaintiff's case in Title VII actions brought by individuals. ${ }^{87}$ First, the plaintiff must establish his prima facie case by showing that a job was available, that he was not hired (or was fired or not promoted), and that he was qualified for the job. ${ }^{88}$ The defendant may then rebut the inference of discrimination by

within sound discretion of trial judge). But cf. Smith v. Universal Servs., Inc., 454 F.2d 154, 157, 158 (5th Cir. 1972) (trial court erred in refusing to admit EEOC investigative report).

84. See Jepsen v. Florida Bd. of Regents, 610 F.2d 1379, 1384-85 (5th Cir. 1980) (trial court acted within its discretion in ordering release of faculty evaluation forms after weighing benefits against potential harm from disclosure of privileged communications). In Weahkee v. Norton, 621 F.2d 1080, 1082 (10th Cir. 1980), the court of appeals reversed the trial court's refusal to grant a former investigator of the EEOC access to EEOC personnel files in his discrimination suit against the Commission. The court favorably cited EEOC v. University of New Mexico, 504 F.2d 1296 (10th Cir. 1974) (EEOC investigation may have access to all personnel files of members of college faculty). But see Keyes v. Lenoir Rhyne College, 552 F.2d 579, 581 (4th Cir.), cert. denied, 434 U.S. 904 (1977) (no abuse of discretion in refusal to allow former professor to discover college's faculty evaluation records). The issue of the scope of discovery in a private Title VII case involving professional employment recently resulted in a professor at the University of Georgia going to jail for contempt rather than revealing how and why he voted at a meeting considering plaintiff's application for a grant of tenure. N.Y. Times, Sept. 14, 1980, at 1, col. 3.

85. 42 U.S.C. $\S 2000 \mathrm{e}-8$ (c) (1976) (prohibits disclosure of information by the EEOC only "prior to the institution of any proceeding under [Title VII]").

86. 411 U.S. 792 (1973).

87. The McDonnell Douglas guidelines were originally applied to private actions under 42 U.S.C. $\$ 2000$ e-5(f) (1976). McDonnell Douglas Corp. v. Green, 411 U.S. 792, 797-98 (1973). The guidelines have been extended to federal employment cases under 42 U.S.C. $\S 2000 \mathrm{e}-16$ (c) (1976). See Williams v. Bell, 587 F.2d 1240, 1245 n.45 (D.C. Cir. 1978); Whiteside v. Gill, 580 F.2d 134, 138 (5th Cir. 1978).

88. 411 U.S. at 802 . The guidelines have been widely applied to promotion, see Kunda v. Muhlenberg College, 621 F.2d 532, 541 (3d Cir. 1980), and to discharge, see McDonald v. Santa Fe Trail Transp. Co., 427 U.S. 273, 281-85 (1976).

The most problematic element in the prima facie showing is the requirement that plaintiff was "qualified" for the job. This requirement can only be fulfilled by showing what the qualifications for the job were; in the context of professional employment, where no written, definitive set of criteria are available, these qualifications can often be ascertained only by inspection of the qualifications of other applicants. See Banerjee v. Board of Trustees, 495 F. Supp. 1148, 1155-56 (D. Mass. 1980), aff'd, 648 F.2d 61 (1st Cir. 1981). But see Powell v. Syracuse Univ., 580 F.2d 1150, 1153 (2d Cir.), cert. denied, 439 U.S. 984 (1978) (proof of mere competence was sufficient to meet qualifications requirement in prima facie case). Some courts have approved the use of statistical evidence in making the prima facie showing. See Sweeney v. Board of Trustees, 569 F.2d 169, 178 (1st Cir.), vacated and remanded, 439 U.S. 24 (1978); Adams v. Reed, 567 F.2d 1283, 1287 (5th Cir. 1978).

Although the McDonnell Douglas guidelines for proving a prima facie case have been frequently applied in the professional and white collar context (the most directly comparable to legislative policymaking aides), see, e.g., Sweency v. Board of Trustees, 569 F.2d 169 (1st Cir.), vacated and remanded, 439 U.S. 24 (1978) (teacher); Smith v. Fletcher, 559 F.2d 1014 (5th Cir. 1977) (government bureaucrat); Whiteside v. Gill, 580 F.2d 134 (5th Cir. 1978) (guidance counselor), some courts have cautioned against using the formula mechanically where there are high numbers of applicants for a 
articulating a legitimate nondiscriminatory reason for the employment action. ${ }^{89}$ The plaintiff may then attack that reason as "pretext" ber of ways that do not require him to prove directly that the defendant intended to discriminate. ${ }^{91}$ In order to obtain judgment, the plaintiff need introduce no direct evidence of discriminatory intent. ${ }^{92}$

The $M c$ Donnell Douglas guidelines, as they have been applied in cases concerning professional employment, would pose serious chilling problems if they were extended to legislative branch employees or applicants in professional or policymaking roles. When, outside the legislative-hiring context, a defendant's justification for a challenged employment action consists of a subjective evaluation of a plaintiff's qualifications or performance, such evaluations ${ }^{93}$ and similar evaluations of other workers or job applicants ${ }^{94}$ have been admitted into evidence. The court typically weighs the defendant's justification and the evidence supporting and refuting it and then determines whether the inference of discrimination created by plaintiff's prima facie case has been successfully rebutted.95

Uncertainties concerning the types and quality of evidence needed for proof of liability would raise for legislators the risk that they could not

single place, see Loeb v. Textron, Inc., 600 F.2d 1003, 1017 n.18 (1st Cir. 1979). The Supreme Court has warned against automatic reliance on the formula. See International Bhd. of Teamsters v. United States, 431 U.S. 324, 358-59 (1977) (alternative methods of proving prima facie case).

89. 411 U.S. at 802-03. Defendant must only "articulate" the reason; he need not prove its validity. See Board of Trustees v. Sweeney, 439 U.S. 24, 25 (1978) (per curiam).

90. 411 U.S. at 805 (plaintiff "must be given a full and fair opportunity to demonstrate by competent evidence that the presumptively valid reasons for his rejection were in fact a coverup for a racially discriminatory decision").

91. For example, the plaintiff may dispute the facial truth of the reason offered, see Johnson v. University of Pittsburgh, 435 F. Supp. 1328, 1365 (W.D. Pa. 1977) (alleged lack of teaching ability), may show that the reason was not applied in the same manner to others, see Kunda v. Muhlenberg College, 621 F.2d 532, 545 (3d Cir. 1980) (master's degree allegedly needed for promotion), may introduce statistical evidence revealing a disparity in pay or representation of those in the plaintiff's class, see McDonnell Douglas Corp. v. Green, 411 U.S. 792, 805 (1973), may show that irregular procedures were used in taking the employment action, see Sweeney v. Board of Trustees, 569 F.2d 169, 173 (1st Cir.), vacated and remanded, 439 U.S. 24 (1978) (failure to give plaintiff reasons for adverse promotion decision), or may point to general evidence of bias or prejudice of the employer, see EEOC v. Tufts Inst. of Learning, 421 F. Supp. 152, 162 (D. Mass. 1975) (reputation of immediate supervisor for sex bias).

92. See note 26 supra.

93. See, e.g., Hochstadt v. Worcester Foundation, 545 F.2d 222, 233-34 (1st Cir. 1976) (evaluation of plaintiff's political activity as detrimental to harmonious working environment of medical institute); Johnson v. University of Pittsburgh, 435 F. Supp. 1328, 1365-68 (W.D. Pa. 1977) (subjective evaluation of teaching and scholarly ability).

94. See, e.g, Whiteside v. Gill, 580 F.2d 134, 137 (5th Cir. 1978) (comparison of diligence and communicative ability of guidance counselors); Falkenheiner v. Legal Aid Soc'y, 471 F. Supp. 429 (M.D. La. 1979), af'd, 629 F.2d 1348 (5th Cir. 1980) (comparison of managerial and leadership abilities of attorney-applicants for directorship of legal aid society).

95. Compare Sweeney v. Board of Trustees, 604 F.2d 106, 112, 113 (1st Cir. 1979), cert. denied, 444 U.S. 1045 (1980) (subjective evaluation of plaintiff in comparison with other faculty members helped buttress prima facie case) with Gilbert v. East Bay Mun. Util. Dist., 19 Empl. Prac. Dec. 6547, 6548-49 (N.D. Cal. 1979) (comparison of plaintiff's "supervisory" ability with others' successfully rebutted prima facie case). 
persuade the fact-finder that they had not discriminated. Like proof in "blue collar" Title VII cases, proof in Title VII cases involving professionals often requires the fact-finder to draw many inferences from circumstantial evidence. ${ }^{96}$ The informal nature of congressional employment procedures could itself support an inference of discrimination. ${ }^{97}$ Although some courts, in light of the complex and subjective nature of employment decisions regarding professionals, have eschewed further inquiry if the defendant articulates a legitimate justification for the employment action, ${ }^{98}$ other courts have awarded relief in spite of the problems of proof. ${ }^{99} \mathrm{Be}-$ cause the approach of the activist courts might be followed in suits involving policymaking aides, legislators, uncertain of their ability to defend themselves, would be deterred from taking employment actions based on legitimate political reasons and from speaking candidly with aides with respect to legislative matters. Again, current speech or debate clause doctrine does not adequately protect against chilling that results from the defendant's awareness that he might fail to persuade the court of his employment decision's legitimacy.

The proof process may chill legislative activity in another way. If, in the course of a Title VII suit against a legislator, the court needed to compare the subjective qualifications of the plaintiff with those of other employees or applicants, ${ }^{100}$ uncertainty about the evidentiary privilege allowed by the speech or debate clause could arise; moreover, such an uncertainty could exist in the mind of any legislator who fears future Title VII litigation. If a legislator is sued for employment discrimination based upon a measure he took for political or ideological reasons, part of the evidence could center on the political and ideological compatibility of the plaintiff with the defendant, and the ideological compatibility of the defendant with his other employees. ${ }^{101}$ Although evidence of legislative pol-

96. See Furnco Constr. Corp. v. Waters, 438 U.S. 567, 576-78 (1978) (discriminatory intent in employment practices may be established inferentially).

97. Staff employment in Congress is often an informal, word-of-mouth procedure. See note 11 supra. Similar practices have already been condemned in the Title VII professional context. Cf. Smith v. Union Oil Co., 17 F.E.P. Cas. 960, 991 (N.D. Cal. 1977) (company's use of present managers' evaluations to hire new managers and supervisors solely from lower level employees perpetuated pattern of discrimination in violation of Title VII).

98. Faro v. New York Univ., 502 F.2d 1229, 1231-32 (2d Cir. 1974) (termination of female professor's employment); Green v. Board of Regents, 335 F. Supp. 249, 250-51 (N.D. Tex. 1971), afT'd, 474 F.2d 594 (5th Cir. 1973) (although female plaintiff had been teaching at university for 25 years, court refused to substitute its judgment for judgment of those with expertise).

99. See Kunda v. Muhlenberg College, 621 F.2d 532, 545 (3d Cir. 1980) (conditional tenure); Sweeney v. Board of Trustees, 569 F.2d 169, 175 (1st Cir. 1978) (retroactive promotion).

100. See p. 1474 supra.

101. In Falkenheiner v. Legal Aid Soc'y, 471 F. Supp. 429 (M.D. La. 1979), for example, the plaintiff lawyer sued for alleged sex discrimination based upon the failure of a legal aid society to choose her as director. The defendant proffered as one of its justifications the lack of compatibility between the plaintiff's ideology and the aims of the society; the defendant suggested that the plaintiff, in contrast to the applicant chosen, was more concerned with law reform and social change than with 
icy is "legislative," and thus inadmissible on speech or debate clause grounds, such evidence is closely related to conceivably admissible evidence regarding general personal compatibility ${ }^{102}$ Uncertain of the scope of his evidentiary protection, a legislator could restrain himself in speaking with aides, ${ }^{103}$ or refuse to fire or not hire an aide. ${ }^{104}$

Remedies. Title VII provides that no equitable remedies shall be allowed unless the plaintiff would not have been injured but for the discriminatory act. ${ }^{105}$ When such relief is sought, and a violation has been proved, the defendant must ordinarily show by "clear and convincing" evidence that he would have taken the employment action even if he had not unlawfully discriminated against the plaintiff. ${ }^{106}$ Establishing the alternative theory of causation poses a problem of chilling for a legislator similar to the problem of chilling that results from uncertainty about the scope of the evidentiary privilege in the initial proof of violation according to the $M c$ Donnell Douglas guidelines. ${ }^{107}$ Political compatibility, or lack thereof, will often be the alternative explanation; because of the vagueness in the legislative-nonlegislative distinction, a legislator may fear that past dealings between employee and legislator concerning policy matters may thus be exposed once again to questioning in court.

Reinstating a higher level employee after litigation presents special remedial problems. Some courts have not hesitated to order reinstatement in

serving the poor. Id.

102. See Double Standards, supra note 5, at 23 (statement of Professor V. Blasi, University of Michigan School of Law) ("The court decisions draw a distinction between actually deliberating and doing other things which might aid your deliberations and support your deliberations, from your thoughts which later show up in the deliberation .... It's somewhat of a formal distinction. It's not so much a functional distinction.")

103. Cf. Herbert v. Lando, 441 U.S. 153, 194 (1979) (Brennan, J., dissenting in part) (without privilege protecting confidentiality of editorial process, discussions among editors would be dampened and "the accuracy, thoroughness, and profundity of consequent publications might well be diminished"). It has often been recognized in speech or debate clause litigation that the evidentiary use of legislative activities can be as great a threat to the legislative process as a lawsuit based on legislative acts. See p. 1467 \& note 51 supra.

104. In Davis v. Passman, 544 F.2d 865, 881 (5th Cir. 1977), affd in part, vacated in part, 571 F.2d 793 (5th Cir. 1978) (en banc), rev'd on other grounds, 442 U.S. 228 (1979), the court of appeals acknowledged the importance of assuring legislators broad discretion in staffing decisions and formulated a qualified immunity to protect this interest from charges of discrimination. See p. 1461 supra. It is unclear whether this immunity serves its intended purpose.

105. 42 U.S.C. $\S 2000$ e-5(g) (1976). See Peele v. Califano, 447 F. Supp. 160, 167 (D.D.C. 1978) (refusal to order retroactive appointment of white plaintiff to superintendency of federal hospital, despite demonstration of impermissible consideration of race in selection process, because government showed that plaintiff would not have been appointed even if consideration of race had not tainted process).

106. See Day v. Mathews, 530 F.2d 1083, 1086 (D.C. Cir. 1976).

107. There are also chilling problems stemming from a distinct risk of nonpersuasion. Establishing the lack of but-for causation places on the legislator the heavy burden of proof by "clear and convincing" evidence. He may doubt his chances of carrying this burden and refuse to take a contemplated employment action in the first place. 
the professional employment context. ${ }^{108}$ Because Congressmen's personal offices are comparatively small, ${ }^{109}$ reinstating an employee in such an office after litigation could be very disruptive. ${ }^{110}$ If the remedy of reinstatement demanded continuing judicial supervision, the disruptive effect would be compounded. ${ }^{111}$ Given the difficulties of dealing with an aide reinstated by court order after litigation, a legislator may refrain from firing an aide for wholly permissible reasons unrelated to discrimination. ${ }^{12}$

\section{Remedies for Chilling}

Courts' expertise in solving chilling problems in the First Amendment area suggests general guidelines for resolution of speech or debate chilling problems. These guidelines, in turn, can be applied in the specific context of Title VII extension in a fashion that preserves equal employment opportunity values.

\section{A. Deriving Remedies from First Amendment Doctrine}

The problem of legislative inhibition through civil litigation has been little explored by the courts, perhaps in part because speech or debate clause issues seldom arise. The courts have, however, dealt extensively with similar problems of chilling in applying the First Amendment's protections for expression. Although there are significant differences between those two constitutional immunities, ${ }^{113}$ they possess the functional similar-

108. Kunda v. Muhlenberg College, 621 F.2d 532, 549 (3d Cir. 1980) (trial court acted properly in awarding reinstatement and tenure conditioned on plaintiff's procurement of master's degree); Tanner v. California Physicians' Serv., 20 Empl. Prac. Dec. 11,773 (N.D. Cal. 1978) (plaintiff in sex discrimination suit ordered reinstated and promoted to management position); Theodore v. Elmhurst College, 421 F. Supp. 355, 358 (N.D. Ill. 1976) (reinstatement appropriate remedy for tenured employee allegedly discharged in violation of Title VII). But see EEOC v. Kallir, Phillips, Ross, Inc., 420 F. Supp. 919 (S.D.N.Y. 1976), aff', 559 F.2d 1203 (2d Cir. 1977) (refusal to reinstate former pharmaceutical advertising executive because of need for complete trust and confidence between parties).

109. The personal staff of a Senator has an average of 31 members. OFFICES, ETHICS, AND PRESSURES, supra note 11 , at 4 .

110. The reinstatement of professional employees to small, closely knit working environments has been criticized. See Note, Employment Discrimination Suits by Professionals: Should the Reinstatement Remedy Be Granted? 39 U. PITT. L. REV. 103, 113-15 (1977).

111. See Loeb v. Textron, Inc., 17 F.E.P. Cas. 1332, 1333 (D.R.I. 1978), rev'd on other grounds, 600 F.2d 1003 (1st Cir. 1979) (reinstatement of successful plaintiff in Age Discrimination in Employment Act suit would entail "repeated applications to the Court with respect to the relationship" between parties and would involve court in management of defendant corporation).

112. Some Congressmen have voiced concern at the prospect of "outsiders" dictating employment decisions within their own offices. See 124 CONG. REC. S18,246 (daily ed. Oct. 11, 1978) (remarks of Sen. Hollings) (internal fair employment board will not be limited to granting traditional remedies and will interfere with legislator's freedom of decision regarding promotions or pay increases).

113. The First Amendment protects not only political expression but also artistic expression, see Kingsley Int'l Pictures Corp. v. Regents of the Univ. of N.Y., 360 U.S. 684, 690 (1959), as well as commercial speech, see Virginia Pharmacy Bd. v. Virginia Consumer Council, 425 U.S. 748, 759-60 
ity of preserving the independence and freedom of the political process. ${ }^{14}$ The courts' basic strategy in First Amendment cases-giving protected activities "breathing space" 115 to reduce chilling-can provide a revised framework for implementing speech or debate clause protections. ${ }^{116}$

\section{The Problem of Substantive Doctrinal Uncertainty}

The First Amendment tradition has recognized that certainty about which activities are protected and which are unprotected from criminal or civil liability can elude persons wishing to exercise the right of expression. ${ }^{117}$ An individual uncertain of his entitlement to engage in some expression without incurring liability may simply abstain from expression, ${ }^{118}$ much as a legislator uncertain of the scope of his legislative immunity may decline to act and thereby risk liability. ${ }^{118}$ The danger in either case is that the actor will be deterred from some activity that the Constitution-either the First Amendment or the speech or debate clause-would protect. In both cases, uncertainty about the applicability of legal doctrine makes the possibility of liability seem too great to the actor; the vagueness of the law

(1976). The speech or debate clause, unlike the First Amendment, helps maintain the constitutional scheme of separation of powers. See p. 1466 supra.

114. Compare Buckley v. Valeo, 424 U.S. 1, 14 (1976) ("[T]he First Amendment affords the broadest protection to such political expression in order 'to assure [the] unfettered interchange of ideas for the bringing about of political and social changes desired by the people." ") (quoting Roth v. United States, 354 U.S. 476, 484 (1957)) with Kilbourn v. Thompson, 103 U.S. 168, 203 (1881) (" 'These [speech or debate clause] privileges are thus secured, not with the intention of protecting the members against prosecutions for their own benefit, but to support the rights of the people, by enabling their representatives to execute the functions of their office without fear of prosecutions, civil or criminal." ") (quoting Coffin v. Coffin, 4 Mass. 1, 27 (1808)). In protecting the political process, the First Amendment and the speech or debate clause make similar behavioral assumptions. Compare NAACP v. Button, 371 U.S. 415, 433 (1963) ("First Amendment freedoms need breathing space to survive . . . .") with McSurely v. McCellan, 553 F.2d 1277, 1295 (1976), cert. denied as improvidently granted sub. nom. McAdams v. McSurely, 438 U.S. 189 (1978) ("The principle lof legislative immunity] is designed to give legislators and their aides a certain measure of elbow-room to pursue legislative activity without the inhibitions that necessarily flow from exposure to suit .....")

115. See NAACP v. Button, 371 U.S. 415, 433 (1963) (when activities protected by First Amendment are implicated, "government may regulate . . . only with narrow specificity").

116. There has been interchange of ideas between the doctrines of official immunities and First Amendment immunities. In New York Times Co. v. Sullivan, 376 U.S. 254 (1964), the Court in part justified its requirement that a plaintiff who is a public official show a high level of mens rea on the part of the defendant-newspaper for allegedly defaming him in his official capacity, by noting that public officials themselves enjoy a similar qualified immunity for allegedly defaming private citizens. The Court noted that both immunities were designed so the public official and the citizen-critic could carry out socially useful activities without inhibition. Id. at 282.

117. Cf. Jacobellis v. Ohio, 378 U.S. 184, 197 (1964) (Stewart, J., concurring) (hard-core pornography unprotected by First Amendment difficult to define, "[b]ut I know it when I see it").

118. See Gooding v. Wilson, 405 U.S. 518, 521 (1972) ("[P]ersons whose expression is constitutionally protected may well refrain from exercising their rights for fear of criminal sanctions provided by a statute susceptible of application to protected expression."); Dombrowski v. Pfister, 380 U.S. 479, 486 (1965) (if those uncertain of scope of First Amendment refrain from protected political activities on account of fear of possible prosecution, society itself may be loser).

119. See p. 1468 supra. 
chills his activity. ${ }^{120}$

The standard response of the courts in the First Amendment area has been to allow persons to succeed in challenging statutes that indiscriminately prohibit both protected and unprotected activities, without requiring the challengers to demonstrate that their own activities were protected. ${ }^{121}$ An "overbroad" statute that punished both protected and unprotected activities, if upheld by the courts, might operate in the future to deter protected expression. ${ }^{122}$ In essence, the court allows only clearly unprotected activities to be prohibited.

Adapting this stratagem to the speech or debate clause context, a court, in deciding whether to allow a civil suit against a legislator, should not limit itself to determining whether an act was "legislative" or "nonlegislative." It should also ask whether the suit would substantially inhibit acts that prior cases have determined to be legislative in nature and therefore protected. A court should not, for example, allow a civil suit based upon a nonlegislative act if the legislator had sufficient reason to believe his action was legislative. Similarly, a nonlegislative act that the actor had reason to believe was legislative should be privileged evidence if disclosing it or questioning the actor about it would chill legislative activity. ${ }^{123}$

120. The Court has applied chilling analysis in other areas of law. See United States v. U.S. Gypsum Co., 438 U.S. 422,441 n.17 (1978) (strict liability for violation of vague antitrust laws may inhibit pro-competitive activity; strict liability employable only for most egregious violations); North Carolina v. Pearce, 395 U.S. 711, 725-26 (1969) (ability of trial judge to impose more severe sentence upon retrial may inhibit exercise of criminal defendant's constitutional rights to attack original conviction; heavier sentence available only upon finding changed circumstances since time of last sentence).

121. In the Court's terminology, "overbroad" statutes were unconstitutional on their face because they punished both protected and unprotected forms of expression indiscriminately. See, e.g., Keyishian v. Board of Regents, 385 U.S. 589 (1967) (state statute requiring, inter alia, that state university teachers declare whether or not they are Communists, found to be so overbroad as to chill rights of political belief and association); Thornhill v. Alabama, 310 U.S. 88 (1940) (broad antiloitering and picketing statute held unconstitutional because it condemned all activities including ones clearly protected).

122. See Note, The First Amendment Overbreadth Doctrine, 83 HARV. L. REv. 844, 872 (1970) ("When there is no clear judge-made line dividing constitutional and unconstitutional applications, the clarity of an overbroad statute on its face is deceptive . . . . A person contemplating action within the literal scope is left in doubt whether his claim of privilege will be upheld, unless his situation is on all fours with that of an carlier claimant.")

123. Once a court has adjudicated that a disputed action was actually nonlegislative in nature, no legislator may thereafter escape liability for that action or for mention of it in a proceeding. This proposal would require the courts to deliver a series of opinions limited to purely prospective effect-that is, not touching the litigants themselves, but all those who undertake the disputed activity after the court's decision is rendered. The Supreme Court has approved this technique. Linkletter v. Walker, 381 U.S. 618, 629 (1965).

The Court, in developing this doctrine of prospective opinion-making, has enumerated three factors for deciding whether to limit a decision to solely prospective effect: (1) a litigant who wishes to secure the benefit of nonretroactivity must show that "the decision to be applied nonretroactively . . . [establishes] a new principle of law, either by overruling clear past precedent . . . or by deciding an issue of first impression whose resolution was not clearly foreshadowed"; (2) the court must determine on the whole "whether retrospective operation will further or retard [the new rule's] operation"; and (3) the court must bear in mind a generalized concern for the inequities of making a new decision retroactive. Chevron Oil Co. v. Huson, 404 U.S. 97, 106-07 (1971). In applying the first prong of the test, the 


\section{The Risk of Nonpersuasion and Burdensome Litigation}

Courts have recognized two other related sources of chilling in the First Amendment area that are significant for the speech or debate clause. Even if an actor believes his contemplated activity would be clearly entitled to immunity from liability, he may be unsure of what evidence will be needed to persuade a judge or jury that his activity was of privileged character. If, for example, a journalist knew that the truth of an alleged defamatory statement would defeat a claim of libel, he might nevertheless refrain from publication because he was unsure whether the facts of the statement, taken in evidence in a libel action, would appear to the judge or jury to be false, ${ }^{124}$ or whether establishing the truth of the statement would be worth the expense and distraction of litigation. ${ }^{125}$ If the information in the publication is true and therefore protected by the First Amendment, his sense of the risk of nonpersuasion and his concern for the burdens of litigation will have chilled exercise of a constitutional right. ${ }^{126}$

Within the speech or debate clause context, a Congressman might abstain from activity he believes protected simply because he thinks the risk of not persuading the fact-finder too great. ${ }^{127}$ In these cases, from the actor's perspective, it may not be any vagueness in a substantive legal rule, but rather some doubt about his chance of success, and the expense in-

Court would determine whether or not a legislator should have been forewarned that his activity would be adjudicated as unprotected. Any limitation to prospective effect would obviously meet the second prong of the Huson test since nonretroactivity serves to prevent chilling of the legislative process. The third prong of the test stresses the concerns for stability and fairness embodied in the first two prongs.

The proposal to employ prospective decisions is similar in effect to the Supreme Court's practice in the overbreadth cases of adjudicating whether a statute prohibits both protected and unprotected activities. Once the Court determines that a statute is overbroad, it will strike the statute down on its face without requiring the person challenging the statute to show that his conduct was protected. See note 121 supra (citing cases). Conceivably, Congress could then amend the offensive statute to cure it of its overbreadth, and a successful challenger would then be on notice that he would not be able to assert the chilling argument in a second litigation.

124. See Curtis Publishing Co. v. Butts, 388 U.S. 130, 152 (1967) (jury's prejudices may cause defendants to doubt their ability to assert truth of alleged defamatory statements as defense).

125. See Herbert v. Lando, 441 U.S. 153, 205 (1979) (Marshall, J., dissenting) (expense of litigation, specifically extensive discovery, may chill journalists' willingness to report controversial news or opinions); Rosenbloom v. Metromedia, Inc., 403 U.S. 29, 53 (1971) (plurality opinion) (same).

126. See Dorfman, The Story Behind the Story, REnDER (Chicago), Feb. 2, 1978, § 1, at 1, 2932 (magazine decided not to run article on alleged CIA connections of several businessmen when one claimed to have exculpatory information that he refused to reveal to magazine's editor).

127. This chilling effect is not limited to any particular statute. For example, a Member of Congress may forego meeting with potential political supporters in preparing for a committee hearing for fear that expenditures by these persons in support of the legislator's reelection would then be regarded as illegal campaign contributions instead of independent political expenditures. See 2 U.S.C. $\S 441 \mathrm{a}(\mathrm{a})(7)(\mathrm{B})(\mathrm{i})$ (1976) ("[E]xpenditures made by any person in cooperation, consultation, or concert, with, or at request or suggestion of, a candidate. . . shall be considered to be a contribution to such candidate.") 
volved in using the facts to claim the rule's benefit, that chills the actor's conduct. ${ }^{128}$

In the First Amendment area, the response of the courts to this type of chilling has been to adjust substantive standards. Thus, in New York Times Co. v. Sullivan, ${ }^{129}$ the Court added a new element to a libel plaintiff's cause of action, a showing of "actual malice," self-censorship of controversial but essentially accurate expression that deserves First Amendment protection. ${ }^{131}$ A lower standard might induce actors uncertain of their ability to persuade a fact-finder of a favorable factual characterization of the expression to refrain from uttering it. In the speech or debate area, if a substantive liability rule or rule of evidence seems to a court unwisely to enhance the legislator-defendant's risk of nonpersuasion, then the court might properly adjust the liability rule or the evidentiary requirement. ${ }^{132}$ Attention to the chilling effects of litigation would thus reduce inhibition of the legislative process, inevitable in any exposure of Congressmen to liability.

\section{B. Reconciliation of Title VII and the Speech or Debate Clause}

The general guidelines developed for speech or debate clause chilling analysis are unnecessary for implementing Title VII remedies for the majority of legislative employees. In order to reconcile the competing values of equal employment opportunity and legislative independence in the more difficult cases of policymaking employees on Congressmen's personal staffs, however, certain restrictions on Title VII enforcement on Capitol Hill should be recognized.

\section{Categories of Title VII Plaintiffs}

There is no speech or debate clause problem in extending full Title VII protection and its concomitant advantages to the majority of legislative employees, for the majority are not on Members' personal staffs and com-

128. Even if the risk of nonpersuasion does not deter a Member of Congress from engaging in contemplated activity, it may still infuence him enough so as to distort his normal course of activity.

129. 376 U.S. 254 (1964).

130. The Court defined "actual malice" in the publication of a defamatory statement as publication with "knowledge that [the statement] was false, or reckless disregard of whether it was false or not." Id. at 280 .

131. See id. at 279 (if truth is only allowed defense to libel allegation, difficulty and expense of proving truth in court may deter would-be critics of official conduct from voicing their criticisms even if they are true).

132. Raising substantive standards changes the nature of relevant evidence by requiring additional evidence to meet the raised substantive standard. However, there are other ways to create evidentiary requirements. For example, in Washington v. Davis, 426 U.S. 229, 239 (1976), the Court not only imposed a substantive standard of actual intent to discriminate, but also required evidence beyond the circumstantial evidence of disproportionate impact of an employment test. 
mittee staffs. Such employees are ordinarily not hired on the basis of political compatibility, and thus the threat of a Title VII suit brought by them would not inhibit deliberation protected by the speech or debate clause. ${ }^{133}$ Indeed, Congress has already extended such protection to state legislative employees not on Members' personal staffs. ${ }^{134}$ On the other hand, committee staff members hired by resolution could not bring a suit under Title VII against committee members for employment discrimination in committee hiring: the litigation would probably draw in question the reasons for the committee members' votes, and voting is a clearly protected legislative activity. ${ }^{135}$ Policymaking employees on Members' staffs occupy a more difficult, middle position.

\section{The Policymaking Aide's Title VII Suit}

Title VII enforcement for the benefit of policymaking, personal staff members must be judicially restricted to avert inhibition of legislators' discussions and deliberations with aides about policy matters within the protective reach of the speech or debate clause. Thus, at both the federal and state levels, ${ }^{136}$ full Title VII protection, as presently construed, cannot be extended to this category of plaintiffs in a way that comports with the purposes of the speech or debate clause. In order to avoid chilling of the

133. See OBEY COMMISSION, supra note 7, at 109 (employees in administrative units of House are removed from political pressure of Members' offices and have few personal loyalties to legislators). A Title VII suit brought by one of these employees would therefore not involve the dangers of embarrassment and breach of confidentiality implicated by a suit by a policymaking personal staff member. See Brief of the United States as Amicus Curiae at 5 n.3, Davis v. Passman, 571 F.2d 79 (5th Cir. 1978) (en banc), rev'd on other grounds, 442 U.S. 228 (1979) (at minimum, speech or debate clause shields legislator with respect to employment decisions above clerical level). For the same reasons, the reinstatement of such employees should not affect a legislator's functioning, as would reinstatement of a policymaking aide. Nonetheless, certain secretaries and other clerical assistants, while not policymaking aides, should be excluded from this group if they perform sensitive tasks such as writing letters on the legislator's behalf.

The Supreme Court has drawn a similar line between policymakers and nonpolicymakers in the patronage firing cases. Employment decisions with respect to nonpolicymaking, nonconfidential positions may not be made on the basis of party affiliation. Branti v. Finkel, 445 U.S. 507, 515-16 (1980); Elrod v. Burns, 427 U.S. 347 (1976).

134. The Equal Employment Opportunity Act of 1972, § 2(5), 42 U.S.C. \& 2000e(f) (1976), in extending Title VII coverage to state government employment, specifically exempted a state legislator's personal staff.

135. Committee resolution is a form of voting and as such is one of the core legislative activities protected by the clause. See p. 1467 supra. Committee staff, both professional and clerical, are hired by committee resolution, in accordance with Senate and House rules. See note 12 supra. See also Eslinger v. Thomas, 476 F.2d 225 (4th Cir. 1973) (state legislators personally immune from suit for passage of resolution barring women from being hired as state senate pages).

136. Although federal separation of powers concerns do not apply to state legislators, much of this Note's analysis depends upon broader concerns of legislative independence, and thus its general conclusions should be applicable to state legislators as well as Members of Congress. See Supreme Court of Va. v. Consumers Union of the United States, 446 U.S. 719, 732 (1980) (state legislators enjoy common-law speech-or-debate type immunity from suits under 42 U.S.C. $\$ 1983$ ); Tenney v. Brandhove, 341 U.S. 367, $372-75$ (1951) (principle of legislative immunity firmly established at both federal and state levels). 
legislative process, a Title VII suit by such an employee requires judicial adjustments of the burden of persuasion, the rules for the admissibility of evidence, and the nature of the remedy applicable.

Burden of persuasion. In a suit by a policymaking employee against a legislator, the plaintiff should be required to produce clear and convincing evidence that the defendant engaged in intentional employment discrimination. The requirement of clear and convincing evidence would place a greater premium on noninferential or direct evidence of intent. ${ }^{137}$ Nevertheless, direct evidence itself, although valuable, would not be required: a plaintiff could instead prove a case through clear and convincing circumstantial evidence. ${ }^{338}$

The requirement of clear and convincing evidence would be most relevant at the "pretext" stage ${ }^{139}$ of the proof process. Allowing a mere preponderance of cirumstantial evidence to prove a Title VII violation would differ little from the highly inferential nature of proof under the $M c D o n-$ nell Douglas guidelines, ${ }^{140}$ thus, the chilling problems due to uncertainty about the evidence needed to persuade the court of nondiscriminatory intent would remain. The requirement of clear and convincing evidence, on the other hand, should reduce chilling by reducing such uncertainty. ${ }^{141}$ In addition, a prospective plaintiff presumably would be discouraged from bringing his complaint to the private action stage of the Title VII process without a clear case. ${ }^{142} \mathrm{~A}$ clear and convincing showing of discriminatory

137. "Direct evidence" consists of noninferential revelations of the defendant's discrimination against the plaintiff or evidence of a generally biased attitude towards members of the plaintiff's class in policymaking positions. The most direct form of evidence would be an admission of discrimination. See Davis v. Passman, 544 F.2d 865, $867 \mathrm{n.1}$ (5th Cir. 1977), affd in part, vacated in part, $571 \mathrm{~F} .2 \mathrm{~d}$ 793 (5th Cir. 1978) (en banc), rev'd on other grounds, 442 U.S. 228 (1979) (Congressman in letter to plaintiff justified dismissal on grounds of sex). Expression of ill-will to the plaintiff by the defendant also qualifies as direct evidence. Cf. Herbert v. Lando, 441 U.S. 153, 164 (1979) (proof of malice in common-law defamation cases could be shown by character or personal relationship between parties).

138. Although discriminatory intent is difficult to prove directly, it has been successfully shown in a number of cases. See, e.g., Davis v. Passman, 442 U.S. 228, 230 n.3 (1979) (admission of intent in discharge letter); Skelton v. Balzano, 424 F. Supp. 1231, 1235 (D.D.C. 1976) (admission of plaintiff's superior that he intended to discriminate against plaintiff and other women); Pace College v. Comm'n on Human Rights, 38 N.Y.2d 28, 34, 339 N.E.2d 880, 882, 377 N.Y.S.2d 471, 474 (1975) (evidence of explicitly discriminatory comments by head of Speech Department of defendant college). One court has posited direct evidence of intent as a suitable substitute in a Title VII suit for a McDonnell Douglas prima facie showing of discrimination. Loeb v. Textron, Inc., 600 F.2d 1003, 1014 n.12 (1st Cir. 1979).

139. See p. 1474 supra (plaintiff has opportunity to show that employer's articulated reason for employment decision was pretext for discrimination).

140. See pp. 1473-74 supra (describing McDonnell Douglas test).

141. Like the requirement of actual malice in the First Amendment libel cases, this requirement will ensure that the person who is in fact carrying on a socially desirable activity will be assured of escaping liability because the evidentiary requirements for liability are high and clear to the factfinder.

142. Cf. Rosenbloom v. Metromedia, Inc., 403 U.S. 29, 52-53 (1971) (plurality opinion) (substantive standard less than "actual malice" in libel cases would encourage burdensome litigation that could inhibit protected conduct). 
intent, of course, would not necessarily be sufficient to establish liability under the proposed standard. As under the present judicial treatment of Title VII, the defendant would still be free to show that his action would have been taken anyway for a legitimate nondiscriminatory reason. ${ }^{143}$

Evidentiary privilege. Even if the plaintiff introduces clear and convincing evidence of intent to discriminate, the speech or debate clause still precludes introduction of evidence of legislative acts. ${ }^{144}$ Because the distinction between legislative and nonlegislative acts is vague, a legislator should be able to block the introduction of acts adjudicated as nonlegislative in the pending suit if the plaintiff cannot demonstrate good reason to believe that the acts were not legislative and privileged ${ }^{145}$ - even after clear and convincing evidence of intent has been produced. Thus, to reduce chilling due to disclosures and inquiries regarding political compatibility and other arguably "legislative" matters, a legislator sued in connection with policymaking aides' employment should be permitted to require that all such evidence not be investigated, discovered, or admitted unless plaintiff can demonstrate that defendant did not have good reason to believe that the acts in question were legislative. ${ }^{146}$ Only clearly unprivileged evidence could be investigated, discovered, or admitted into evidence, and burdensome and intrusive discovery would be correspondingly reduced. ${ }^{147}$

Remedies. Title VII provides for a wide variety of remedies, such as backpay and injunction against future discrimination. ${ }^{148}$ The reinstate-

The panel opinion in Davis v. Passman, 544 F.2d 865, 880 n.25 (5th Cir. 1977), aff'd in part, vacated in part, 571 F.2d 793 (5th Cir. 1978) (en banc), rev'd on other grounds, 442 U.S. 228 (1979), argued that a qualified immunity, coupled with judicious use of summary judgment procedures, would diminish the risk of burdensome, frivolous constitutional suits. As the court itself admitted, however, the constitutional mandate against employment discrimination is clear, 544 F.2d at 881 , and it would therefore seem that a legislator could not assert that in good faith he misinterpreted the law. Id. at 882.

143. See p. 1476 supra (defendant may show lack of but-for causation to avoid imposition of equitable remedies).

144. United States v. Helstoski, 442 U.S. 477, 488-89 (1979).

145. This evidentiary bar would parallel the immunity that a legislator should arguably enjoy against liability for an activity the character of which he had good reason to believe was legislative. See p. 1479 supra (general standard to decrease chilling due to vagueness in legislative/nonlegislative distinction). Legislators in subsequent litigation should not be able to make the same argument with respect to similar evidence since they would have been put on notice by the prior decision.

146. The mechanism for establishing privilege would be for the plaintiff to request discovery of a class of evidence. The legislator-defendant would then claim that the evidence was of legislative acts. The court would then conduct an in camera inspection and would make specific rulings on limiting discovery. All evidence not clearly unprivileged would be excluded. The court, however, would be free to make prospective rulings on close decisions. The court would act in similar fashion when the EEOC attempts to compel compliance with its subpoena for information during an administrative investigation.

147. The existence of an evidentiary privilege should aid the district court in holding discovery to a strict standard of relevance. Cf. Herbert v. Lando, 441 U.S. 153, 205-06 (1979) (Marshall, J., dissenting) (trial judge should hold discovery in libel suits by public figures to strict standard of relevance to prevent chilling arising from fear of burdensome litigation).

148. See note 28 supra. 
ment remedy, however, should not be granted in the case of policymaking employees because their presence in a legislative office after suit would disrupt the legislative process. ${ }^{149}$ Reinstatement would require continual policing by the judiciary, ${ }^{150}$ an activity in conflict with the goals of the speech or debate clause. Faced with the possibility of such a drastic remedy, a legislator might be deterred from firing an incompatible aide, or be highly circumspect in hiring a controversial applicant. ${ }^{151}$

\section{Conclusion}

The extension of Title VII to the legislative branch involves a delicate task of reconciling legislative independence with equal employment opportunity values. In the interest of an untramelled legislative process, a proper analysis of the speech or debate clause demands that several restrictions on the normal Title VII suit be imposed in cases involving policymaking personal staff aides.

149. See p. 1477 supra.

150. See note 111 supra.

151. See p. 1477 supra. 